\title{
Physicochemical technology of pretreatment of dairy waste water using natural waste
}

\author{
Alla Smolyanichenko ${ }^{1,2 *}$ \\ ${ }^{1}$ Don State Technical University, 1 Gagarin Sq., 344003, Rostov-on-Don, Russia \\ ${ }^{2}$ The State Maritime University named after Admiral F.F. Ushakov, 8, Sedova st., 344006, Rostov- \\ on-Don, Russia
}

\begin{abstract}
The growth in the production of dairy products entails the problem of treating wastewater from the operation of dairy plants. This article discusses the possibility of using a purification technological scheme using sorbents from natural waste, which is an alternative to the traditional one, which includes a biological stage. In this study, activated biochar from rice husks and graphite are used as sorbents. As a result of purification according to the proposed scheme, the quality of the treated water corresponds to the normative indicators when discharged into the city sewage network.
\end{abstract}

\section{Introduction}

The dairy sector has peaked over the past 30 years $(+2 \%)$ in 2020 for major products. For example, the production of drinking milk increased $(+2 \%)$, cheeses $(+15 \%)$, butter $(+$ $16 \%)$, ice cream $(+39 \%)$, skimmed milk powder $(+45 \%)$ and dry whole milk $(+14 \%)$, dry whey $(+18 \%)$, etc. (fig. 1) [1]. Along with the increase in the production of dairy products, there is also an increase in the volume of wastewater to be treated.

Wastewater from the dairy industry is highly concentrated due to the significant content of organic pollutants - polysaccharides and high molecular weight protein compounds, as well as nitrogen and phosphorus compounds (Table 1).

The concentration of pollutants $(\mathrm{g} / \mathrm{t})$ in wastewater can be determined using the equation (1):

$$
\mathrm{C}=\left(\mathrm{P}_{1} \mathrm{C}_{1}+\mathrm{P}_{2} \mathrm{C}_{2}+\ldots \mathrm{P}_{\mathrm{n}} \mathrm{C}_{\mathrm{n}}\right) /\left(\mathrm{N}_{1}+\mathrm{N}_{2}+\ldots \mathrm{N}_{\mathrm{n}}\right)
$$

where $\mathrm{C}$ is the concentration of pollutants in wastewater $\left(\mathrm{g} / \mathrm{m}^{3}\right), \mathrm{C}_{1}, \mathrm{C}_{2}$ and $\mathrm{Cn}$ are the concentration of pollutants per unit of milk or dairy product loss $(\mathrm{g} / \mathrm{t})$, and $\mathrm{N}_{1}, \mathrm{~N}_{2}$ and $\mathrm{N}_{\mathrm{n}}$ are wastewater discharges per unit of milk or produced dairy products $\left(\mathrm{m}^{3} / \mathrm{t}\right)[2]$.

\footnotetext{
* Corresponding author: arpis-2006@mail.ru
} 


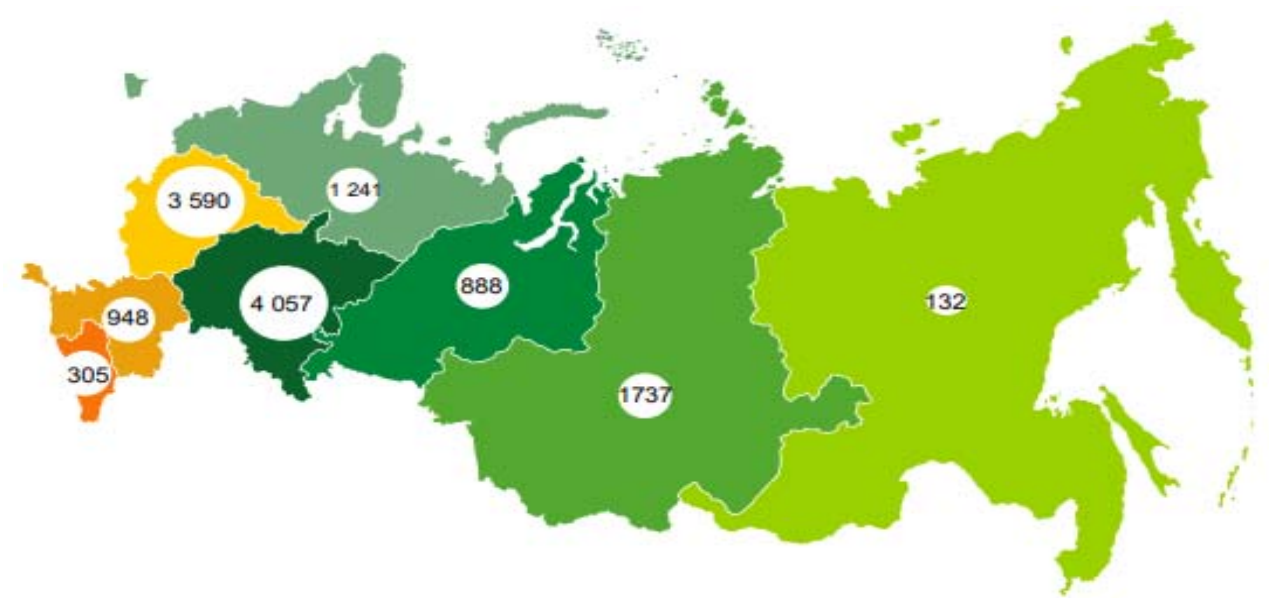

North Caucasian Federal

District (FD)

Northwestern FD

Southern FD

Volga FD

Siberian FD

Central FD

Ural FD

Far Eastern FD

Fig.1. Milk production in the Russian Federation, thousand tons (09.2020) [1]

Table 1. Composition of various dairy products [3].

\begin{tabular}{|c|c|c|c|c|c|c|}
\hline Product & $\begin{array}{c}w(\text { dry } \\
\text { matter })\end{array}$ & $\begin{array}{c}w \\
\text { (fat) }\end{array}$ & $\begin{array}{c}w \\
\text { (protein) }\end{array}$ & $\begin{array}{c}w \\
\text { (lactose) }\end{array}$ & COD & BOD $_{20}$ \\
\hline & $\%$ & $\%$ & $\%$ & $\%$ & $\mathrm{~g} / \mathrm{kg}$ & $\mathrm{g} / \mathrm{kg}$ \\
\hline Whole milk & $11.5-12.5$ & $3-4$ & 3.3 & 4.8 & 192.9-218.6 & $135.5-156.2$ \\
\hline Skimmed milk & $8.3-8.47$ & $0.02-0.06$ & 3.3 & $4.7-4.9$ & $112-115.3$ & $72.4-75.1$ \\
\hline Buttermilk & $7.7-8$ & $0.4-0.86$ & 3 & 4 & $104.5-111.9$ & $72.4-75.1$ \\
\hline Cheese whey & $6-6.2$ & $0.05-0.2$ & $0.75-1.0$ & $4.5-4.8$ & $72-77$ & $51.6-55.9$ \\
\hline $\begin{array}{c}\text { Second cheese } \\
\text { whey }\end{array}$ & 5.7 & $<0.01$ & 0.3 & 4.6 & - & - \\
\hline Casein Whey & 6.1 & $<0.01$ & 0.5 & 4.7 & - & - \\
\hline Cream & $40.4-43$ & $33-35$ & 2 & 3 & $871-936.5$ & $695-747$ \\
\hline Dry whey permeate & 95.2 & - & 5.9 & 83 & 1034.3 & - \\
\hline $\begin{array}{l}\text { Decontaminated } \\
\text { permeate }\end{array}$ & $23.5-25$ & - & $2.6-3.7$ & $14-16$ & - & - \\
\hline
\end{tabular}

Loss of milk and dairy products, production wastes, reagents used for rinsing containers; impurities removed from the surface of containers, technological equipment, floors, domestic wastewater are part of the wastewater of dairies. 
This type of wastewater has a number of features that must be taken into account when choosing a technological scheme for treatment facilities. These features include the unevenness of the inflow and the instability of the concentration of pollutants arising as a result of volley discharges of wastewater during periodic flushing of technological equipment.. Peak effluent discharges can be up to 4 times the average. Also, wastewater is characterized by fluctuations in ph - a low ph value as a result of the use of organic acids when washing equipment - up to 2-2.5 and when washing with alkalis - 10-10.5, as well as a significant content of organic substances, the concentration of pathogenic bacteria can exceed the maximum permissible values thousands of times.

Wastewater treatment of dairy enterprises mainly includes the use of mechanical, physicochemical and biological methods (Fig. 2) [4]. The advantages of physicochemical processes include their effectiveness in removing emulsified compounds, but this method is not enough in terms of reducing the COD value. As a rule, this function is performed by biological wastewater treatment systems due to the presence of highly biodegradable pollutants.

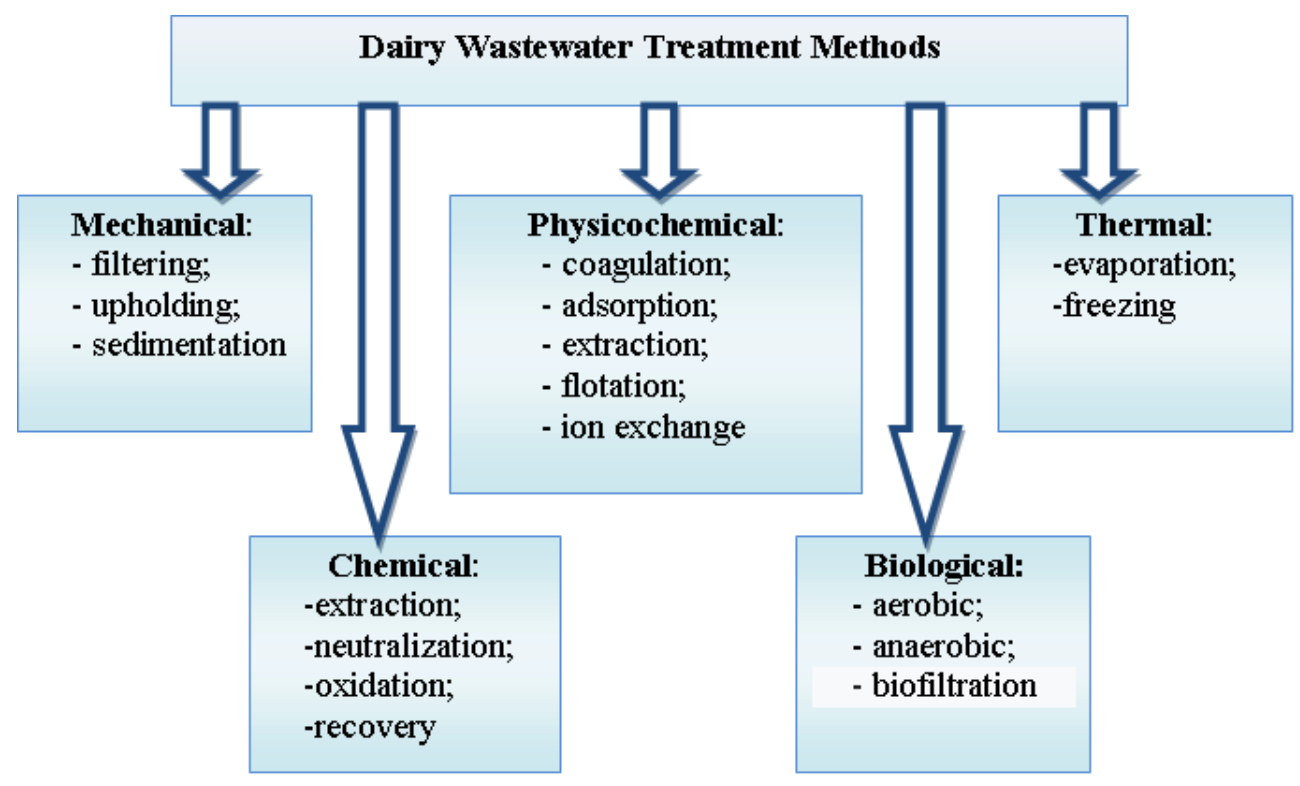

Fig.2. Existing dairy wastewater treatment methods

With insufficient treatment of wastewater from dairy plants when they are discharged into the city sewage network, a number of difficulties arise for the further operation of the sewage system, the most significant of which is the deposition of fats on the walls of pipelines, as well as the critical content of highly concentrated organic pollutants.

Thus, the main purpose of the research in this article is the development and implementation of effective methods for pretreatment of wastewater from dairy plants, including sorption technologies using natural materials.

\section{Materials and methods}

In the presented article, electro- and physicochemical methods of pretreatment of wastewater from dairies are used: electroflotation, reagent treatment and sorption through loading from waste products of natural origin (Fig. 3). 


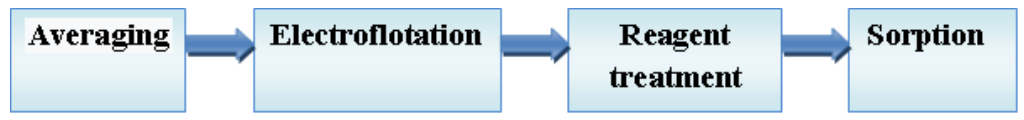

Fig.3. Proposed technological scheme of dairy plant wastewater treatment

Electroflotation was carried out by means of insoluble titanium electrodes with a threecomponent anode coating (OIRTA), including oxides of ruthenium (Ru), iridium (Ir), and platinum (Pt) (Fig. 4, 5) [5]. OIRT electrodes are quite stable in liquids with different $\mathrm{pH}$ values. Since the deposited layers of ruthenium dioxide are more stable, an alkaline medium is preferable in practice to ensure an efficient electrochemical process.

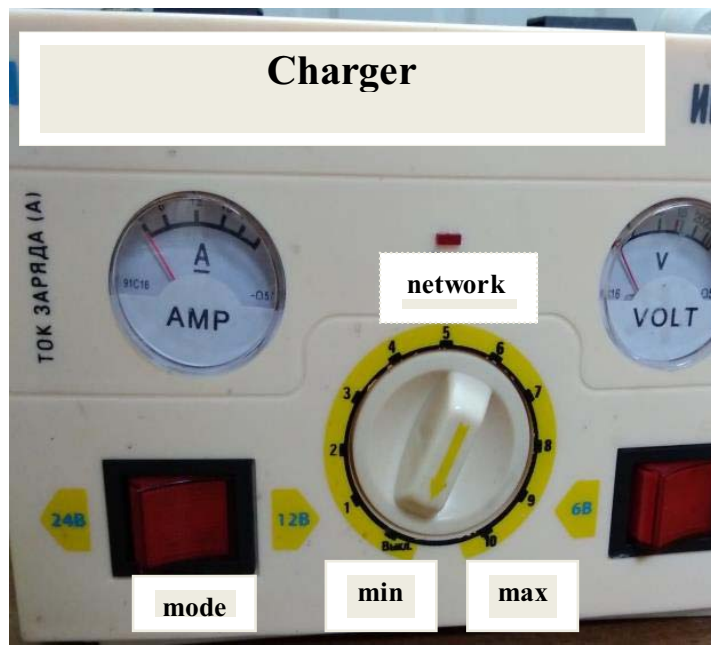

Fig.4. Power source

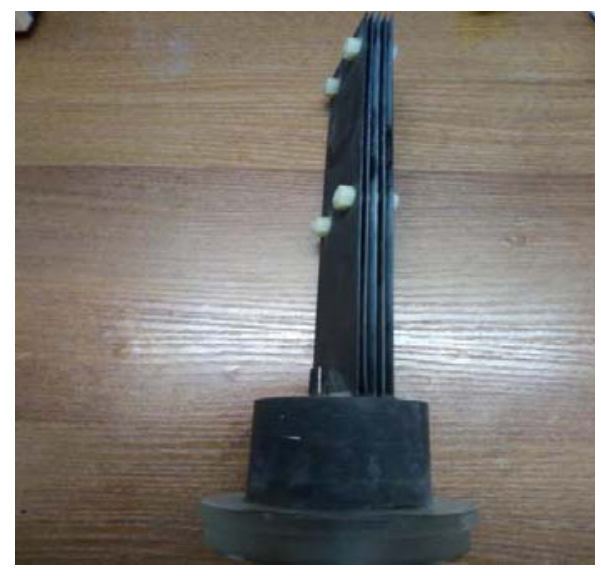

Fig.5. Laboratory cartridge electroflotator.

As a result of the electroflotation process, many different types of free radicals are formed [6]. It is known that electroflotation includes electrochemical and - physical effects on the treated wastewater and pollution in it with an insignificant amount of heat released.

The process occurs in the space charge region near the electrode (anode or cathode) surface of the electrochemical system with nonequilibrium transfer of charge by electrons across the electrode-electrolyte interface. The particles (radicals) formed in this way are highly reactive. In addition, electric current behaves like the strongest oxidizing or reducing agent..

Two types of interaction points act on the upper layer of the anode electrode: the first type is characterized by physical adsorption of $\mathrm{HO} \cdot$ radicals, and the second is characterized by the binding of adsorbed $\mathrm{HO} \cdot$ radicals with the atoms of the oxide crystal lattice, which is the cause of the formation of higher oxides (chemisorbed "active oxygen"):

$$
\mathrm{MOx}+\mathrm{H}_{2} \mathrm{O} \rightarrow \mathrm{MOx}(\mathrm{HO} \bullet) \operatorname{ads}+\mathrm{H}++\mathrm{e}^{-}
$$

The oxidative process of the medium of organic origin at points with characteristic adsorption of physical $\mathrm{HO}$ - radicals, proceeds mostly with the mineralization of the organic part of the substance according to the chemical reaction (3) with the release of $\mathrm{CO}_{2}$ and $\mathrm{H}_{2} \mathrm{O}$, and in the process of obtaining fragmentarily oxidized chemical compounds, the chemisorbed "active oxygen" interacts by equation (4): 


$$
\begin{gathered}
\mathrm{R}+\mathrm{z} \operatorname{MOx}(\mathrm{HO} \bullet) \rightarrow \mathrm{CO}_{2}+\mathrm{H}_{2} \mathrm{O}+\mathrm{z} \mathrm{MOx}+\mathrm{z} \mathrm{H}++\mathrm{z} \mathrm{e}- \\
\mathrm{R}+\mathrm{MOx}+1 \rightarrow \mathrm{RO}+\mathrm{MOx}
\end{gathered}
$$

The destruction of the hydration shell of proteins in wastewater as a result of electroflotation leads to their coagulation and ensures the release of proteins into a concentrate from the first minutes of processing. In addition, electric current rupture of noncovalent bonds supporting the globular structure of the protein and activation of ionogenic R-groups of amino acid residues can lead to the formation of new bonds and, consequently, the aggregation of protein molecules.

The use of reagent treatment at the next stage of purification makes it possible to achieve destabilization and destroy the solvation-hydration shells of fat particles, combining them into larger complexes with high sedimentation properties

Mixed coagulant SKIF180 was used as a reagent. The product contains polyoxychloride aluminum $\mathrm{Al}(\mathrm{OH}) \mathrm{aClb}$ and cationic flocculant - polydiallyldimethylammonium chloride (polyDADMAC). Characteristics of SKIF180: mass fraction of aluminum oxide $\left(\mathrm{AL}_{2} \mathrm{O}_{3}\right), \%$ - 12.0-17.0, mass fraction of chlorine $\left(\mathrm{Cl}^{-}\right), \%$ - 16.0-24.0, mass fraction of cationic flocculant FL-45: 9, 4\%, $\mathrm{pH}-$ 0.5-3.0.

The final stage of wastewater pretreatment included sorption in a dynamic mode through a filtering load from the waste of the agro-industrial complex - activated biochar of rice husk and from the waste of the electrode plant - graphite without activation [7-9].

The possibility of practical application of rice husk has a number of areas - raw materials for the production of amorphous silicon dioxide with a low cost, silicon carbide, as well as the production of carbon-containing sorbents [10-14].

The chemical composition of rice husks mostly includes cellulose and lignin, which are organic compounds, as well as silica, which is a mineral compound (Table 2).

\begin{tabular}{|c|c|c|c|c|c|c|c|c|c|}
\hline \multirow[b]{2}{*}{$\begin{array}{l}\text { Raw } \\
\text { materials }\end{array}$} & \multicolumn{9}{|c|}{ Content, \% } \\
\hline & C & $\mathbf{H}$ & $\mathbf{O}$ & $\mathbf{N}$ & $\mathbf{K}$ & $\mathbf{S i}$ & $\mathrm{Ca}$ & Mg & Al \\
\hline Rice husk & 40.80 & 5.38 & 44.42 & 1.16 & 0.97 & 7.00 & 0.10 & 0.11 & 0.06 \\
\hline
\end{tabular}

Table 2. Rice husk chemical composition [15].

In preparation for the experiment, rice husks were washed with distilled water, subjected to chemical activation with $2 \% \mathrm{NaOH}$ alkali solution for 8 hours, washed again with distilled water, and then dried naturally for a day. The prepared activated material was carbonized for 40 minutes at a temperature of $600^{\circ} \mathrm{C}$ under pyrolysis conditions.

Activated carbons from various materials are quite effective sorbents. Coals are produced from raw materials that contain carbon, including also from graphite.

The structure of graphite is a continuous series of layers parallel to the main plane and consisting of hexagonally bonded carbon atoms. The distance between adjacent carbon atoms in the plane of the layer is $0.142 \mathrm{~nm}$, and between the layers - $0.335 \mathrm{~nm}$. Each atom in a layer is bonded to three neighboring ones [154]. This structure leads to anisotropy of the physical properties of graphite in two directions: perpendicular and parallel to the layers.

Table 3. Chemical composition of graphite.

\begin{tabular}{|c|c|c|}
\hline \multicolumn{3}{|c|}{ Content, \% } \\
\hline C & S & Fe \\
\hline 99.69 & 0.12 & 0.19 \\
\hline
\end{tabular}

For the experiment, the graphite was washed with distilled water without subsequent activation. 


\section{Results}

Laboratory studies were carried out on the wastewater of a dairy plant, the composition of which is presented in Table 4. The aim of the research was to achieve water quality indicators sufficient for discharge into the city sewage network.

Table 4. The chemical composition of the studied wastewater of the dairy plant and the equired parameters of the quality of treatment when discharged into the city sewage network.

\begin{tabular}{|l|c|c|c|}
\hline \multicolumn{1}{|c|}{ Indicator } & $\begin{array}{c}\text { Units } \\
\text { measurement }\end{array}$ & The original & $\begin{array}{c}\text { MPC discharge } \\
\text { into the city sewage } \\
\text { network }\end{array}$ \\
\hline $\mathrm{Ph}$ & - & $6.5 \pm 0.2$ & $6.0-9.0$ \\
\hline Suspended substances & $\mathrm{mg} / \mathrm{dm}^{3}$ & $904 \pm 90$ & 300.0 \\
\hline Phosphorus $\mathrm{P}_{\text {gen }}$ & $\mathrm{mg} / \mathrm{dm}^{3}$ & $17.1 \pm 4.3$ & 12.0 \\
\hline Ammonium $\mathrm{NH}_{4}{ }^{+}$ & $\mathrm{mg} / \mathrm{dm}^{3}$ & $35.8 \pm 7.5$ & - \\
\hline BOD & $\mathrm{mg} / \mathrm{dm}^{3}$ & $1830 \pm 220$ & $300-500$ \\
\hline COD & $\mathrm{mg} / \mathrm{dm}^{3}$ & $2929 \pm 439$ & $500-700$ \\
\hline Ammonia nitrogen $\mathrm{HNO}_{3}$ & $\mathrm{mg} / \mathrm{dm}^{3}$ & 48.7 & 50.0 \\
\hline
\end{tabular}

Wastewater before treatment was averaged and then subjected to electroflotation treatment (Fig. 6) for 10 minutes. The electroflotator is a laboratory cartridge (Fig. 5), consisting of titanium plates $(5 \mathrm{pcs})$. The current source was a charger (Fig. 4) with the set mode current $\mathrm{I}=18 \mathrm{~A}$ and voltage $\mathrm{U}=12 \mathrm{~V}$. After electrochemical treatment, a SKIF180 reagent with a dose of $\mathrm{D}=1 \mathrm{mg} / \mathrm{L}$ was introduced into the wastewater to coagulate the contaminants. The stirring time was taken as $\mathrm{t}=2 \mathrm{~min}$ with a speed of $45 \mathrm{rpm}$, and the settling time was $\mathrm{t}=20 \mathrm{~min}$.

After settling, the wastewater was subjected to sorption treatment, which consisted of filtration through two types of sorbents: the waste of the electrode plant - graphite and activated biochar from the waste of the agro-industrial complex - rice husk. The laboratory installation of the filter consists of a container with a diameter of $\mathrm{D}=6 \mathrm{~cm}$, filled with a sorption material with a layer height of $10 \mathrm{~cm}$. The treated water was supplied from top to bottom through a distributor, i.e. in free-flow mode. The results of the pretreatment of the dairy plant wastewater according to the proposed technological scheme are presented in Table 5 .

Chemical analyzes were carried out in an accredited laboratory of JSC "YuVChEM" using the following measuring instruments: a multiparameter liquid analyzer "Ecotest2000", a 2V-151 drying cabinet, a VLR-200g balance, a UNICO spectrophotometer mod. 1201, photometer Expert-003, liquid analyzer "Expert-001-4-0.1. 
Table 5. Results of analysis of waste water after treatment.

\begin{tabular}{|l|c|c|c|c|c|}
\hline \multicolumn{1}{|c|}{ Indicator } & $\begin{array}{c}\text { Units } \\
\text { measurement }\end{array}$ & Graphite & $\begin{array}{c}\text { Efficiency. } \\
\mathbf{\%}\end{array}$ & $\begin{array}{c}\text { Rice } \\
\text { husk }\end{array}$ & $\begin{array}{c}\text { Efficienc } \\
\mathbf{y} . \mathbf{\%}\end{array}$ \\
\hline \multicolumn{1}{|c|}{$\mathrm{Ph}$} & - & $6.4 \pm 0.2$ & - & $\mathbf{1 0 . 4} \pm 0.2$ & - \\
\hline $\begin{array}{l}\text { Suspended } \\
\text { substances }\end{array}$ & $\mathrm{mg} / \mathrm{dm}^{3}$ & $110 \pm 11$ & 87.83 & $\mathbf{1 1 . 8} \pm 2.4$ & $\mathbf{9 8 . 6 9}$ \\
\hline Phosphorus $\mathrm{P}_{\text {gen }}$ & $\mathrm{mg} / \mathrm{dm}^{3}$ & $3.4 \pm 0.9$ & 80.12 & $\mathbf{4 . 5} \pm 1.1$ & $\mathbf{7 3 . 6 8}$ \\
\hline Ammonium $\mathrm{NH}_{4}{ }^{+}$ & $\mathrm{mg} / \mathrm{dm}^{3}$ & $23 \pm 4.8$ & 35.71 & $\mathbf{9 . 7} \pm 2$ & $\mathbf{7 2 . 9 1}$ \\
\hline $\mathrm{BOD}_{5}$ & $\mathrm{mg} / \mathrm{dm}^{3}$ & $762 \pm 91$ & 58.36 & $\mathbf{3 1 4} \pm 38$ & $\mathbf{8 2 . 8 4}$ \\
\hline $\mathrm{COD}$ & $\mathrm{mg} / \mathrm{dm}^{3}$ & $2193 \pm 329$ & 25.13 & $\mathbf{3 9 9} \pm 60$ & $\mathbf{8 1 . 8 1}$ \\
\hline $\begin{array}{l}\text { Ammonia } \\
\text { nitrogen } \mathrm{HNO}_{3}\end{array}$ & $\mathrm{mg} / \mathrm{dm}^{3}$ & 39.6 & 18.69 & 16.3 & 66.53 \\
\hline
\end{tabular}

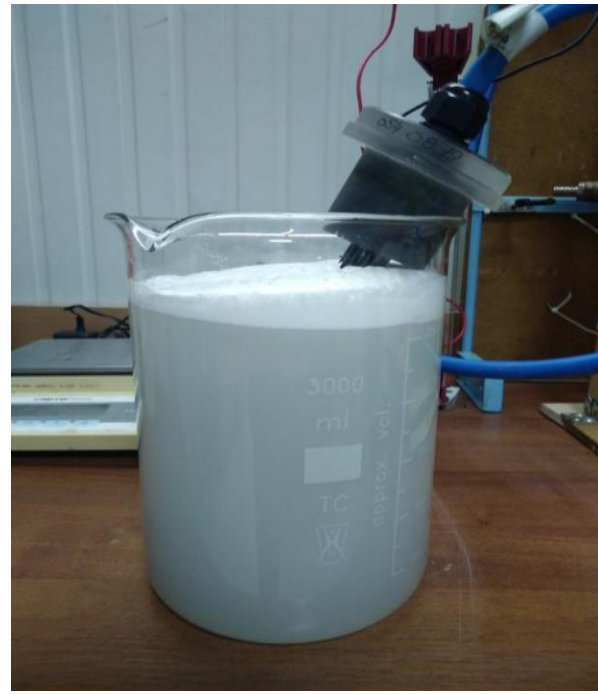

Fig.5. Electroflotation process.

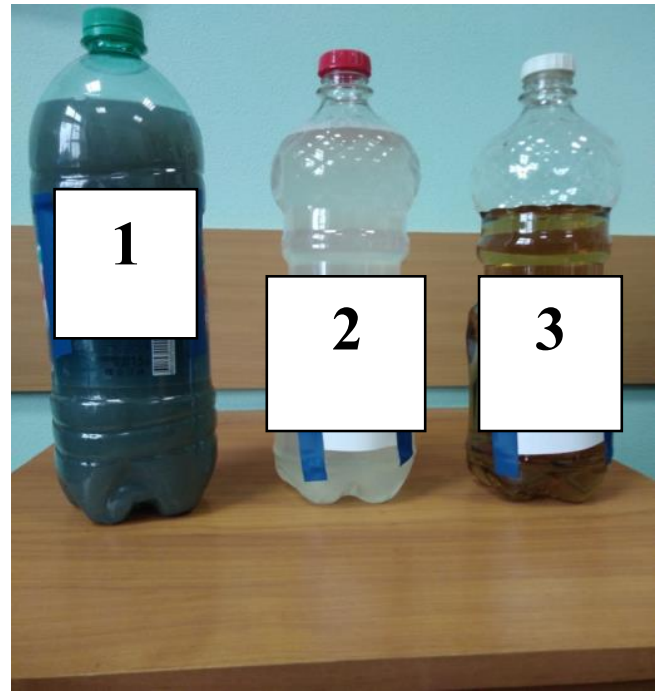

Fig.6. 1- Initial water; 2- Graphite; 3 - Rice husk.

\section{Discussion}

According to the results given in Table 5, the selected technological scheme of pretreatment of wastewater from a dairy plant with sorption of rice husk through biochar is capable of providing the required quality of discharged water.

It should be noted that the proposed technology coped with the primary task of reducing the concentration of difficult-to-oxidize organic matter at a fairly high level. As follows from the data of laboratory studies of the purification method using rice husk biochar, the efficiency in reducing the content of $\mathrm{BOD}_{5}$ and $\mathrm{COD}$ was $82.84 \%$ and $81.81 \%$, respectively. That is, having received at the outlet after the sorption filters the concentration of the above biological contaminants in the treated wastewater in the amount of $314 \mathrm{mg} / \mathrm{l}$ and $399 \mathrm{mg} / \mathrm{l}$, which do not contradict the requirements for the quality of wastewater discharged into the city sewage network, it is possible to exclude the use of biological methods. It should also be said that the sorbent from the waste of the electrode plant, which showed a lower result, is a promising material for this direction. The composition of the 
"charge" includes carbon with a percentage of $99.69 \%$, i.e. additional studies are required to assess the effectiveness of the sorbent during its chemical activation.

\section{Conclusions}

Thus, taking into account the results of laboratory studies, in the course of the work, the sufficient efficiency of the wastewater treatment scheme for dairy plants was established, including only three stages. The undoubted advantage of this technology is the absence of the effect of the discharge of synthetic surfactants and other toxic substances on the final quality of the treated wastewater. At the same time, biological wastewater treatment plants have a fairly high level of sensitivity in relation to such factors.

In turn, when using industrial waste as sorbents, the urgent issue of their disposal finds a solution. Moreover, waste recycling not only does not entail financial losses, but also allows you to open new profitable industries, which cannot but have a positive effect on the state of both the environment and the economy of the regions involved.

\section{References}

1. Overview of the milk and milk products market for 9 months of 2020 // Center for Industry Expertise of the RSHB FSBI Center for Agroanalytics under the Ministry of Agriculture of Russia - 2020. URL: https:// specagro.ru/analytics/202011

2. S. Shete, Bharati, N. P. Shinkar, International Journal of Current Engineering and Technology, 1611-1615 (2013)

https://www.researchgate.net/publication/286182856_Dairy_industry_wastewater_sour ces_characteristics_its_effects_on_environment

3. A. K. Slavov, Food Technol Biotechnol, 55(1), 14-28 (2017)

4. G.V. Sakash, A.F. Kolova, T.Y. Pazenko, Sewage treatment on milk processing enterprises, Bulletin of KrasGAU, 8, 97-103 (2016)

5. V. A. Kolesnikov, V. I. Ilyin, A. V. Kolesnikov, Theoretical foundations of chemical technology, 53 (2), 205-228 (2019)

6. A. Kapałka, H. Baltruschat and C. Comninellis, Preparation, Electrochemistry, Characterization and Applications, 237-260 (2011)

DOI: $10.1002 / 9781118062364 . \operatorname{ch} 10$

7. N. Serpokrylov, A. Smolyanichenko, V. Nelidin, N. Serpokrylov, E3S Web of Conferences, 175, 1-8 (2020)

8. N. Serpokrylov, A. Smolyanichenko, S. Starovoitov, E3S Web of Conferences, 175, 1$11(2020)$

9. K. B.Guillaume, N.S. Serpokrylov, A.S. Smolyanichenko, E.G. Cheblakova, V.A. Gorina, Russian Journal of Non-Ferrous Metals, 61(1), 112-118 (2020)

10. L.N. Fesenko, E.D. Khetsuriani, D.S. Larin, Optimization of fish protection system to increase technosphere safety, IOP Conference Series: Materials Science and Engineering, 262 (2017) URL: https://iopscience.iop.org/article/10.1088/1757$899 \mathrm{X} / 262 / 1 / 012174$

11. A.A. Dordzhiev, A.G. Dordzhiev, V. A. Onkaev, Journal of Environmental Management and Tourism. Biannually, Editor in Chief Ramona PÎRVU University of Craiova. - Romania, VIII 5(21), 130-135 (2018)

12. J.Akansha, P.V.Nidheesh, Ashitha Gopinath, K.V.Anupama, M.Suresh Kumar, 253 (2020) URL: https://doi.org/10.1016/j.chemosphere.2020.126652 
13. M. Biron, Elsevier, 195 (2017)

14. E.I. Vialkova, O.V. Sidorenko, E.S. Glushchenko, Qualitative composition and local pretreatment of dairy wastewaters, IOP Conference Series: Materials Science and Engineering, 687 (2019) doi:10.1088/1757-899X/687/6/066049

15. T. G. Ambaye, M. Vaccaril, E. D. van Hullebusch, A. Amrane, S. Rtimi, International Journal of Environmental Science and Technology (2020) URL:

https://doi.org/10.1007/s13762-020-03060-w 